\title{
粥状動脈硬化症における AGEの役割*
}

$\begin{array}{lllll}\text { 東 隆 } \text { 行 }^{1,2} & \text { 久 米 修 } \text { 一 }^{3} \\ \text { 佐 野 裕 } \text { 之 }^{1} & \text { 陣 内 } & \text { 良 } \text { 映 }^{1} \\ & & & \text { 七里 } & \text { 元 } \text { 亮 }^{2}\end{array}$

I.はじめに

高血糖状態に伴い種々の生体蛋白が糖によってメイ ラード反応をうけている．この反応は蛋白のアミノ基と糖 のアルデヒド基が反応しシッフ塩基を経てアマドリ転位生 成物に至る前期反応と，さらに，これが長期間の複雑な反 応を経て蛍光, 褐色変化, 分子間および分子内架橋を特徵 とする後期反応生成物 (AGE) に至る後期反応に分けられ る ${ }^{1)}$. 最近, AGE に対する特異抗体が開発され ${ }^{2-4)}$, ヒ卜水 晶体クリスタリンで加齢に伴い $\mathrm{AGE}$ 量が増加すること5) や透析患者の手根管アミロイド沈着部位 ${ }^{6}$ ，糖尿病患者の 腎組織7) (腎メサンギウム領域, 血管壁, 尿細管) および冠 動脈硬化巣 ${ }^{8)}$ に AGE の蓄積が報告されており, AGE が老 化や糖尿病合併症の病態発生に関与することが想定されて いる.

今回, われわれは AGE が動脈硬化病変の発生, 進展に関 与することを示唆する結果を得た。すなわち, 抗 AGEモ， クローナル抗体 (6D12) を用いて, 剖険例のヒト大動脈の 動脈硬化病変における AGE の分布ならびに細胞内局在を 明らかにし9),さらに, この免疫組織化学的解析より得られ た結果に基づき，動脈壁における AGE 蓄積の機序につい て in vitro の実験により細胞生物学的に解析を行った ${ }^{10,11)}$.

\section{II. 材料と方法}

\section{2)リガンドの調製}

LDL (比重 $1.019 \sim 1.063 \mathrm{~g} / \mathrm{ml}$ ) は健常正脂血症ヒト血清 より超遠心法によって分離し, $1 \mathrm{mM}$ EDTA 含リン酸 buffer (PBS) で透析した.アセチル LDL は LDL を無水酢 酸で処理して調製した。酸化 LDL は LDL $5 \mu \mathrm{M}$ の硫酸 銅で処理して調製した.AGE-牛血清アルブミン (BSA) は

* 1995 年 11 月, 平成 7 年度日本動脈硬化学会冬季大会 (東京)において発表。

1 熊本大学医学部第二生化学, ${ }^{2}$ 代謝内科,

3 同 第二病理

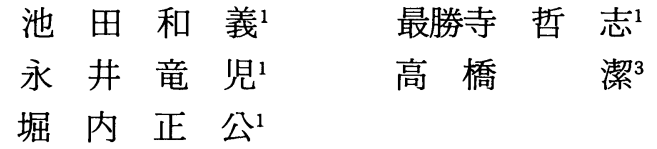

$2.0 \mathrm{~g}$ の BSA と $0.3 \mathrm{~g} / \mathrm{ml}$ の D-glucos $10 \mathrm{ml}$ とを 40 週間, $37^{\circ} \mathrm{C}$ で incubate して調製した.

\section{2) 組織サンプル}

組織サンプルは, 死後 2 5 時間の病理解剖時に, 25 例の 胸部下行大動脈から採取した。標本は PLP 固定液で 4 時間 固定後， $10 \%, 15 \%$ および $20 \%$ のサッカロースを含むPBS で洗浄した。 その後, 包埋剤にて包埋し, 超薄切片を作製 した.

\section{3) 抗 体}

抗 AGE モノクローナル抗体 (6D12) は，AGE-BSA を $\mathrm{BALB} / \mathrm{c}$ マウスに免疫して作製した。ママクロファジ $(\mathrm{M} \phi)$ の認識には抗ヒト $\mathrm{M} \phi$ モノクローナル抗体である EBM11 と PM-2K を使用し, 平滑筋細胞 (SMC) のマー カーとして，抗ヒトアクチンモノクローナル抗体の HHF35を用いた。

\section{4) 免疫組織化学}

切片に対して，それぞれの抗体を用いて，酵素抗体間接 法による免疫染色を行った。

\section{5) 免疫二重染色}

AGE 陽性細胞が M $\phi$ または SMC のどちらに由来する のかを解析するために 6D12 と，PM-2K または HHF35を 用い二重染色を行った。

\section{6) 細胞}

(1) スカベンジャーレセプター (MSR) 導入細胞の単 離

MSR 遺伝子導入細胞は Freeman らの方法で単離し た ${ }^{12)}$. Chinese hamster ovary (CHO) 細胞は非動化 10\% FCS を含む F12 にて培養した。ウシ II 型 MRS 発現べクター pXSRII はポリブレン法で CHO 細胞に導入した. MSR 陽 性コロニーの選択のために細胞はMAC培地 (FCLPDS5\%, メバロン酸 $250 \mu \mathrm{M}$, アセチル LDL $3 \mu \mathrm{g} / \mathrm{ml}$, コ ンパクチン $40 \mu \mathrm{M}$ を含む F12 培地) で培養した. DiI 標識 アセチル LDLの取り込みが特に高かったクローン (CHO-SRII) を今回の実験に使った。 
(2) マウス腹腔マクロファージ

MSR ノックアウトマウスから腹腔洗浄により採取した 非刺激腹腔細胞をプレートに接種し，2 時間培養後に付着 した細胞を実験に用いた。

(3) ラビット平滑筋細胞

ラビット胸部大動脈より explant 法により培養した中膜 SMCの 4〜7継代を実験に用いた。細胞はDMEM 10\% FCS (medium A) にて培養した。

7) レセプターアッセイ

細胞は 24 穴プレートに接種, subconfluent になったとこ ろで実験を始めた. PBSで 1 回洗浄後, $37^{\circ} \mathrm{C}$ に加温した

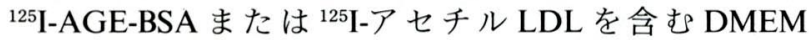
3\% BSA (medium B) を $1 \mathrm{ml}$ 添加し, 非標識リガンドのあ るなしで 3〜24 時間培養後, 培地は取り除き $1 \%$ BSA 含 PBS および, PBS の各 $1 \mathrm{ml}$ で 3 回充分に細胞を洗った. 培 地中の TCA 可溶性画分の放射活性を測定し細胞分解量と し, 細胞は $0.1 \mathrm{~N}$ の $\mathrm{NaOH} て ゙$ 可溶化しその放射活性を細胞 取り込み量とした。

$4^{\circ} \mathrm{C}$ の結合実験は細胞を ${ }^{125}$ I-AGE-BSA を含む medium Bで 2 時間，氷上にて incubateした後細胞を $0.1 \mathrm{~N}$ の
$\mathrm{NaOH}$ で可溶化しその放射活性を細胞結合量とした。

\section{III. 結果および考察}

\section{1) ヒト動脈硬化巣における AGE の分布 ${ }^{9)}$}

抗 AGE 抗体 (6D12) による免疫染色では, AGE は 30 歳以上のほとんどの症例で細胞外に沈着し, 動脈硬化病巣 の内膜表層, 中膜にびまん性の陽性像, 内膜の atheromatous core に顆粒状の陽性像がみられた。また，35歳以 上の症例の半数以上では, 内膜の細胞内に $\mathrm{AGE}$ 蓄積が認 められた。動脈硬化巣をその進行により diffuse intimal thickening (DIT), fatty streak (FS), atherosclerotic plaque (AP) に分類すると DIT ではごく少数の細胞が AGE 陽性 を示すのに対し，FS および Fig. 1-A に示すように AP の fibrous cap では多数の泡沫細胞に著明な $\mathrm{AGE}$ 蓄積がみら れた。 atheromatous core では細胞外のびまん性の陽性像が 確認されたが，細胞内の顆粒状の陽性像は減少していた。 AP の AGE 陽性の泡沫細胞において，細胞種の同定のた めM $\phi$ および SMC 特異マーカー抗体を用いて二重染色 を行うと, AGE 蓄積細胞は M $\phi$ (Fig. 1-B), SMC (Fig. 1-C) および両者の細胞に由来する泡洙細胞であることが判明し

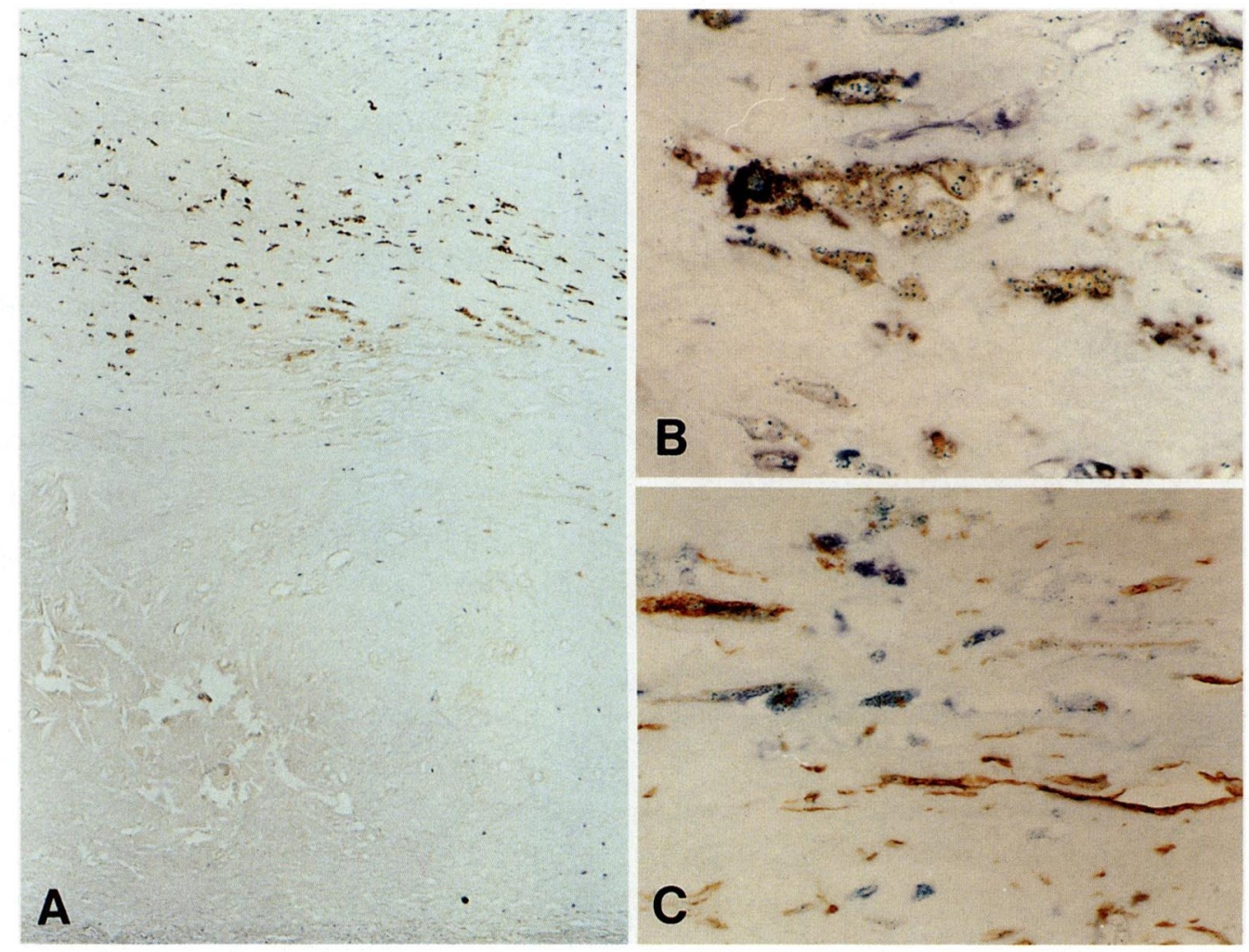

Fig. 1 Immunohistochemical staining of intracellular AGE accumulation in the atherosclerotic plaques. In the atherosclerotic plaques of 66-year-old male, intracellular AGE accumulation occurs mostly in PM-2K-positive foam cells (B) and HHF 35-positive smooth muscle cells (C). Taken from Reference (9). 

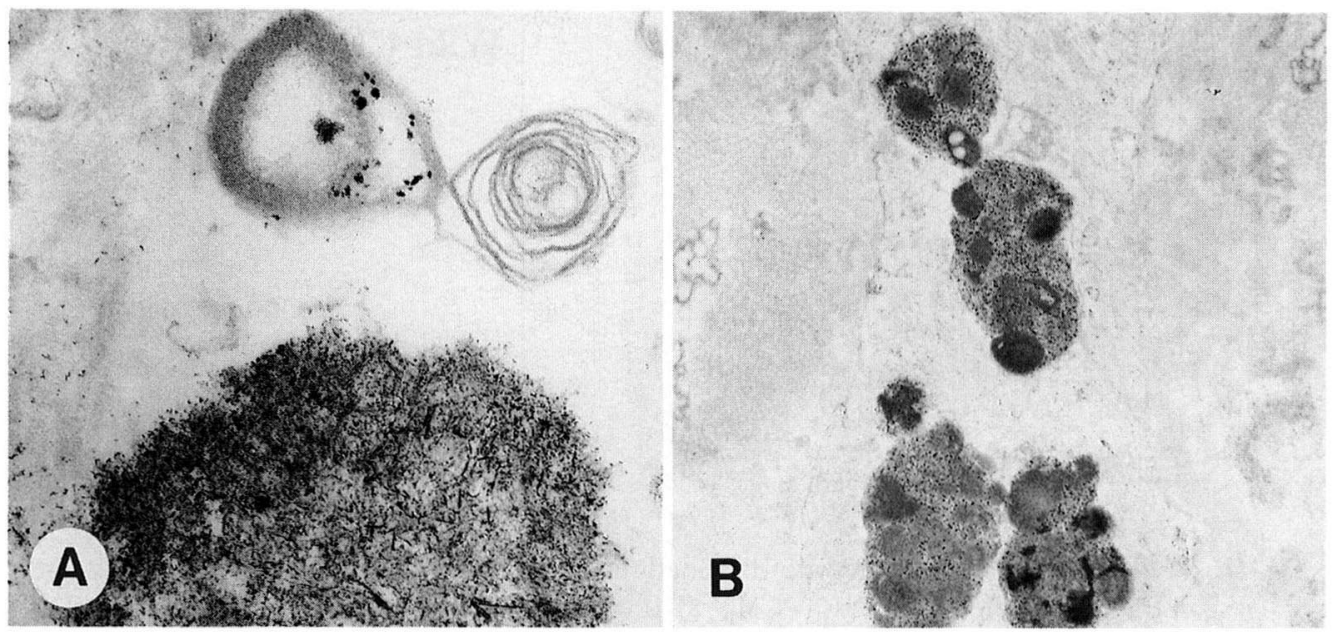

Fig. 2 Immunoelectron microscopical localization of AGEs in macrophage (A) and smooth muscle cell (B). A, Two lipid vacuoles show positive reactions for both 6D12 and acid phosphatase, particularly intense in the lower one, while a myelin figure (MF) is negative for both. B, In the smooth muscle cell, five globular coalesced 6D12-positive granules are found, all showing a positive cytochemical reaction for acid phosphatase.

A. $\times 28,800$, B. $\times 51,700$. Taken from Reference $(9)$.

た. AGE の細胞内局在を免疫電顕にて解析すると, AGE 陽性像は, $\mathrm{M} \phi$ 内の小胞及び脂肪滴にみられた。この $\mathrm{AGE}$ 陽性の脂肪滴は酸フォスファターゼ染色陽性であり (Fig. 2-A), ライソゾームであると考えられた. SMC内にも AGE と酸フォスファターゼ両者が陽性の vesicle を認めた (Fig. 2-B).したがって, 細胞外に生じた AGEがこれらの細
胞によってエンドサイトーシスされた結果, 細胞内蓄積が 生じる可能性が考えられた. そこで, 次に in vitro の実験系 で AGE 蛋白と M $\phi$ 及び SMC との相互作用を検討した.

\section{2) AGE 蛋白と $\mathrm{M} \phi$ との相互作用 ${ }^{10)}$}

牛の II 型マクロファージスカベンジャーレセプター (MSR) の発現べクターを導入した CHO-SRII 細胞におい
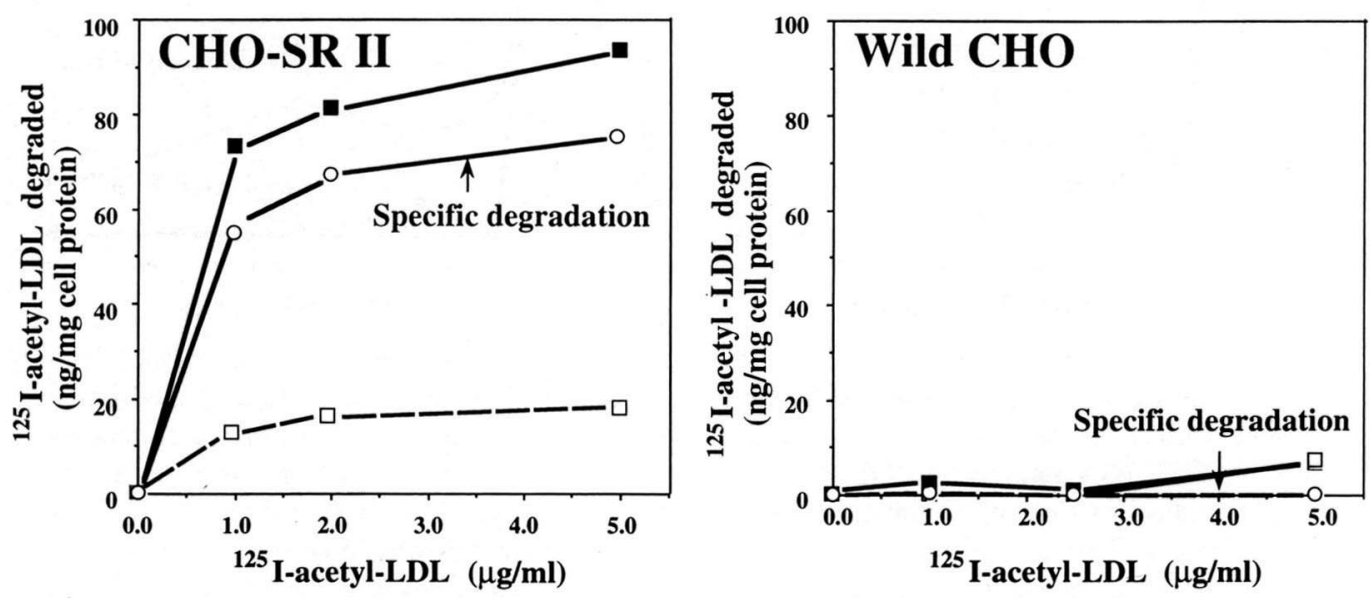

Fig. 3 Endocytic degradation of ${ }^{125}$ I-acetyl-LDL by CHO-SRII cells and untransfected wild CHO cells. CHO-SRII cells or untrancefected $\mathrm{CHO}$ cells $\left(2 \times 10^{5}\right)$ were cultured in $1 \mathrm{ml}$ of MAC medium for $48 \mathrm{hr}$ at $37^{\circ} \mathrm{C}$. The cells were incubated for $5 \mathrm{hr}$ at $37^{\circ} \mathrm{C}$ with the indicated concentrations of ${ }^{125} \mathrm{I}$-acetyl-LDL in the absence or presence of 50 a50-fold excess amount of unlabeled acetyl-LDL. The cells were washed and the cell-associated radioactivity and degradation of ${ }^{125}$ I-acetyl-LDL were determined. The specific celldegradation $(\mathrm{O})$ for $\mathrm{CHO}-\mathrm{SRII}$ cells and for untrancefected $\mathrm{CHO}$ cells were plotted after correcting for nonspecific cell-degradaion $(\square)$ (total minus nonspecific values). Taken from Reference (10). 

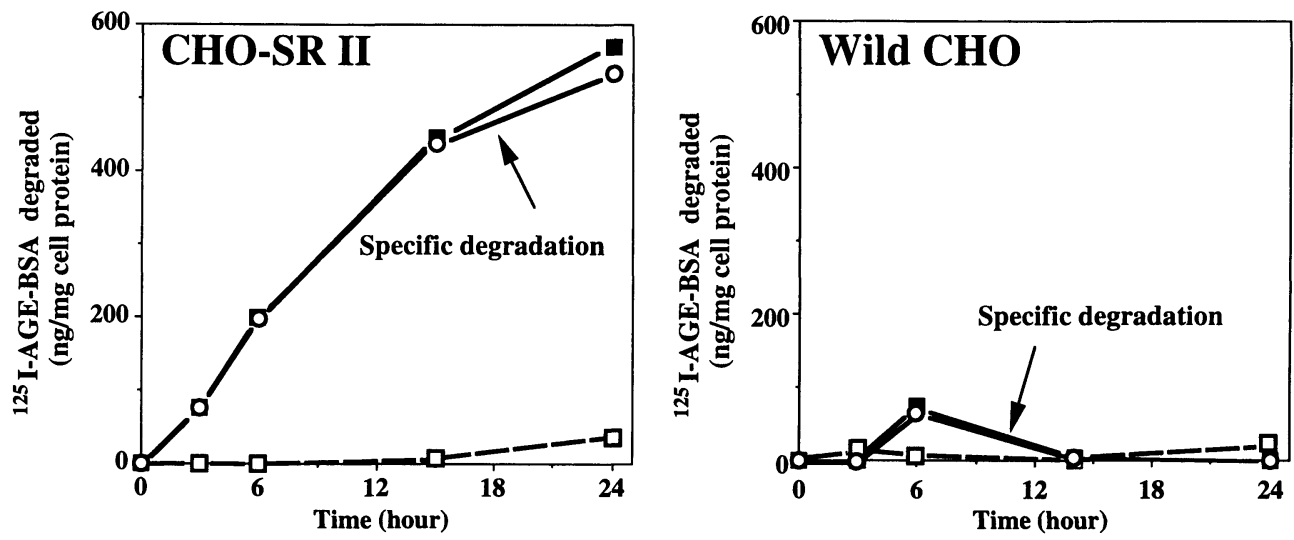

Fig. 4 Time dependency of endocytic degradation of ${ }^{125}$ I-AGE-BSA by CHO-SRII cells and untranfected wild CHO cells. CHO-SRII cells or untrancefected cells $\left(2 \times 10^{5}\right)$ in $1 \mathrm{ml}$ of MAC medium were cultured for $48 \mathrm{hr}$ at $37^{\circ} \mathrm{C}$. The cells were incubated in $1 \mathrm{ml}$ of medium B containing $1 \mu \mathrm{g} / \mathrm{ml}$ of ${ }^{125} \mathrm{I}$-AGE-BSA for the indicated times at $37^{\circ} \mathrm{C}$ in the absence or presence of $50 \mu \mathrm{g} / \mathrm{ml}$ of unlabeled AGE-BSA. The cells were washed and the cell-associated radioactivity and degradation of ${ }^{125} \mathrm{I}$-AGE-BSA were determined. The specific cell-degradation $(O)$ for CHO-SRII cells and for untrancefected $\mathrm{CHO}$ cells were plotted after correcting for non-specific degradation ( $\square$ ). Taken from Reference (10).
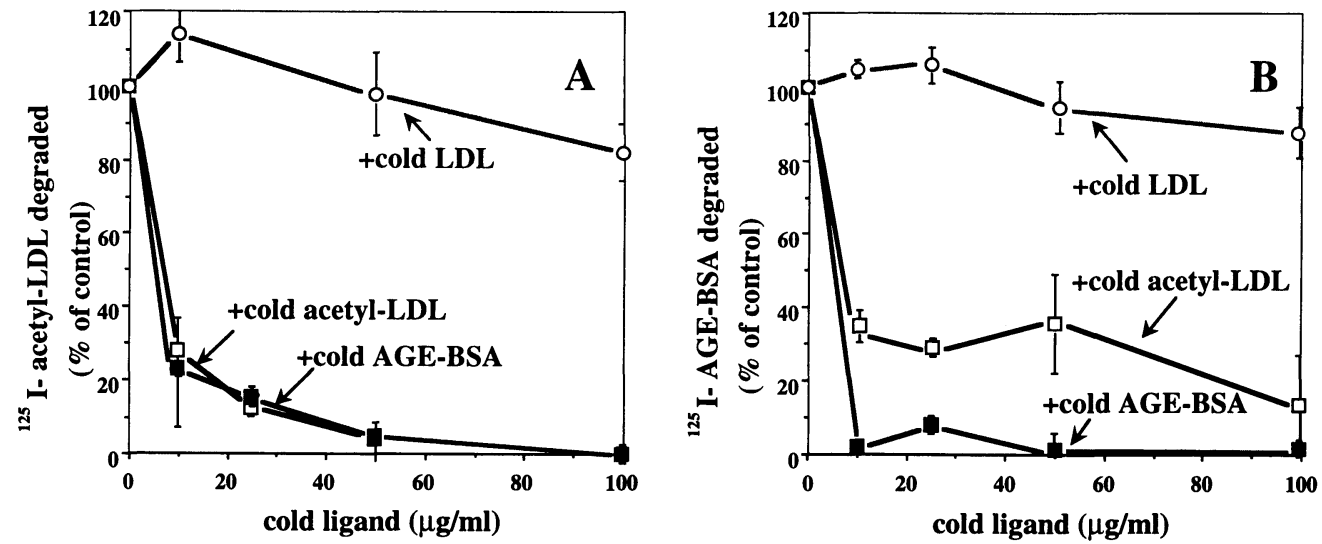

Fig. 5 Cross-competitive effects of AGE-BSA and acetyl-LDL on their degradation by CHOSRII cells. A, CHO-SRII cells were incubated for $16 \mathrm{hr}$ at $37^{\circ} \mathrm{C}$ in $1 \mathrm{ml}$ of medium B with $1 \mu \mathrm{g} / \mathrm{ml}{ }^{125} \mathrm{I}$-acetyl-LDL in the presence of various concentrations of unlabeled AGE-BSA ( $\square$ ), acetyl-LDL $(\square)$ or LDL (O). The cells were washed to determine the radioactivities of degradation as descried in the text. The $100 \%$ values of the celldegradation determined in the absence of unlabeled ligands was $150 \mathrm{ng} / \mathrm{mg}$ cell proteins/ $16 \mathrm{hr}$, respectively. B, Under identical conditions, CHO-SRII cells were incubated for 16 hr with $1 \mu \mathrm{g} / \mathrm{ml}$ of ${ }^{125} \mathrm{I}$-AGE-BSA in the presence of unlabeled AGE-BSA ( $\square$ ), acetyLDL $(\square)$ or LDL $(\bigcirc)$. The degradation of ${ }^{125}$ I-AGE-BSA were determined as descried in the text. The $100 \%$ values of degradation determined in the absence of unlabeled ligands were $0.5 \mu \mathrm{g} / \mathrm{mg}$ cell proteins/ $16 \mathrm{hr}$, respectively. Each bar denotes the standard deviation (SD). Experimental points without SD indicate that SD was less than $2 \%$. Taken from Reference (10). 
て実験を行った。まず，本細胞では wild-CHO 細胞に比較 して有為に ${ }^{125}$ I-アセチル LDL を分解し MSR の発現が確 認された (Fig. 3)。次に, この細胞において ${ }^{125}$ I-AGE-BSA の経時的な分解について解析を行うと, CHO-SRII 細胞で は wild-CHO 細胞と比較して ${ }^{125}$ I-AGE-BSA の分解量は経 時的に有意に増加し 24 時間で $0.55 \mu \mathrm{g} / \mathrm{mg}$ cell protein に達 した (Fig. 4)。このことから CHO-SRII 細胞は ${ }^{125} \mathrm{I}-\mathrm{AGE}-$ BSA を取り込み分解することが明らかとなった。さらに， 本細胞に扔いて AGE-BSA の認識部位とアセチル LDL の 認識部位の相違を明らかにするためそれぞれのリガンドの 分解に対して競合阻害実験を行った。まず， ${ }^{125}$ I-アセチル LDL の分解は過剰の非標識 AGE-BSA より完全に阻害さ れた (Fig. 5-A)。逆に ${ }^{125}$ I-AGE-BSA の分解は過剰の非標 識アセチル LDL で 80-90\% 程度阻害された (Fig. 5-B). 以 上の結果より AGE-BSA が MSR により認識されエンドサ イトーシスされることが明らかとなった。

われわれは，M申における AGE 蛋白処理において MSR の関与をさらに詳細に解析するために，児玉らによって作 成された MSR ノックアウトマウスを用いて実験を行った (未発表データ)。ノックアウトマウスより採取した腹腔

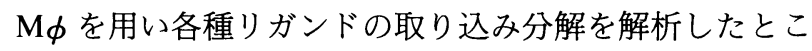
ろ, 本来のリガンドである ${ }^{125}$ I-アセチル LDL の分解は Wild を $100 \%$ とすると Homoでは $90 \%$ 以上減少した。ま た，これと平行して行った実験では ${ }^{125}$ I-AGE-BSA の分解 はWild を100\%とすると Homoでは 70-80\%まで減少し た。これらの結果より, M $\phi$ においては AGE 蛋白の大部分 は MSR で認識されエンドサイトーシスをうけることが明 らかとなった。

AGE 蛋白がレセプターを介してどのような現象を M $\phi$ にひきおこすのかは興味のある点である。われわれは AGE-蛋白が GM-CSF の分泌を介してマウス腹腔 M $\phi$ の 増殖を誘導することや, マウス $\mathrm{M} \phi$ の細胞株である RAW264.7 細胞ではウロキナーゼ型のプラスミノーゲンア クチベータの活性を上昇させることを報告している.

\section{3) AGE 蛋白と SMC との相互作用}

一方，SMCには一般に MSR が発現しないことから， MSR 以外のレセプターが AGE 蛋白の取り込みに関与し ていることを考え, ラビット培養 SMC を用い ${ }^{125} \mathrm{I}-\mathrm{AGE}-$ BSA の $4^{\circ} \mathrm{C}$ での結合実験を行うと, AGE-BSA は解離定数 $4.0 \mu \mathrm{g} / \mathrm{ml}$ と高い親和性で SMC に結合した. また，レセプ ターへの結合後の現象を $37^{\circ} \mathrm{C}$ での取り込み分解により解 析すると ${ }^{125}$ I-AGE-BSA の分解量は濃度依存性に増加し, $\mathrm{M} \phi$ と同様にエンドサイトーシスをうけることが明らか となった。

さらに，この現象は AGE-BSA だけでなく AGE-へモグ ロビンによっても有為に阻害され，本レセプターは AGE
共通の構造をリガンドとして認識していることが考えられ た。ところが, MSR のリガンドであるアセチル LDL や酸 化 LDL では $30 \%$ 程度と有意に阻害されないことから, 本 レセプターは MSR とは異なるレセプターと考えられた。

SMC の AGE レセプターの機能を解析するために SMC の遊走を検討した. AGE-BSA はコントロールの 2 倍程度 の細胞遊走能を誘導しており, これは陽性コントロールの PDGF-BB と同レベルであった。一方，BSA やアセチル LDL では有為に低い遊走しか認めなかった。 checker board 解析によると,この遊走は方向性のある chemotaxis であっ た。

\section{IV. ま と め}

今回の研究により AGE がヒト粥状動脈硬化病変部の細 胞外マトリックスのみならず, $\mathrm{M} \phi$ および, $\mathrm{SMC}$ 由来泡沫 細胞に集中して存在し, この細胞内蓄積が $\mathrm{M} \phi$ においては MSR, SMC においてはMSR と異なるAGEレセプターを 介するエンドサイトーシスによる現象であることが示唆さ れた。さらに，われわれの現在までの解析の結果，上記に 述べたように AGE 蛋白は $\mathrm{M} \phi$ の増殖作用 ${ }^{13)}$ ，M $\phi$ におけ るウロキナーゼ型のプラスミノゲンアクチベータの活性上 昇作用 ${ }^{14)}$ あるいはSMC における細胞遊走作用 ${ }^{11)}$ を有する ことが示唆されており，おそらく，これらのレセプターを 介する現象ではないかと考えられる。

以上, 動脈硬化病変部における $\mathrm{AGE}$ 蓄積および $\mathrm{AGE}$ 蛋白の細胞に対するさまざまな作用が明らかとなったが, $\mathrm{AGE}$ 蓄積が動脈硬化病変の発生にとって原因なのか単な る結果なのかは明らかではない15).今後, この点を解析して いきたい.

最後に本研究は東京大学先端科学技術研究センター児 玉龍彦教授との共同研究であり，ここに深謝致します。

\section{文献}

1) Maillard LC: Action des acides amines sur les sucres; formation des melanoidines par voie methodique. CR Acad Sci Paris, 154: 66-68, 1912

2) Horiuchi $S$, Araki N, and Morino $Y$ : Immunochemical approach to characterize advanced glycation end products of Maillard reaction; evidence for the presence of a common structure. J Biol Chem, 266 : 7329-7332, 1991

3) Makita Z, Vlassara H, Cerami A, and Bucala R: Immunochemical detection of advanced glycosylation end products in vivo. J Biol Chem, 267: 5133-5138, 1992

4) Mitsuhashi $T$, Nakayama $H$, Itoh $T$, Kuwajima $S$, Aoki $\mathrm{S}$, Asumi $\mathrm{T}$, and Koike $\mathrm{T}$ : Immunochemical detection of advanced glycation end products in renal cortex from STZ-induced diabetic rat. Diabetes, 42: 826-832, 1993

5) Araki N, Ueno N, Chacrabarti B, Morino $Y$, and Horiuchi S : Immunochemical evidence for the presence 
of advanced glycation end products in human lens proteins and its positive correlation with aging. J Biol Chem, 267: 10211-10214, 1992

6) Miyata T, Oda O, Inagi R, Iida Y, Araki N, Yamada N, Horiuchi S, Taniguchi N, Maeda K, and Kinoshita T : $\beta_{2}$-Microglobulin modified with advanced glycation end products is a major component of hemodialysisassociated amyloidosis. J Clin Invest, 92: 1243-1252, 1993

7) Yamada K, Nakano H, Nakayama M, Nozaki O, Miura Y, Suzuki S, Tsuchida H, Mimura N, Araki N, and Horiuchi S: Immunohistochemical study of human advanced glycosylation end products (AGE) in chronic renal failure. Clin Nephrol, 42: 354-361 1994

8) Nakamura Y, Horii Y, Nishino T, Shiiki H, Sakaguchi Y, Kagoshima T, Doi K, Makita Z, Vlassara H, and Bucala R: Immunohistochemical localization of advanced glycosylation end products in coronary atheroma and cardiac tissue in diabetes mellitus. Am J Pathol, 143 : 1649-1656, 1994

9) Kume S, Takeya M, Mori T, Araki N, Suzuki H, Horiuchi S, Kodama T, Miyauchi Y, and Takahashi K : Immunohistochemical and ultrastructural detection of advanced glycation end products in atherosclerotic lesions of human aorta using a novel specific monoclonal antibody. Am J Pathol, 147 : 654-667, 1995

10) Araki N, Higashi T, Mori T, Shibayama R, Kawabe $Y$, Kodama T, Takahashi K, Shichiri M, and Horiuchi S : Macrophage scavenger receptor mediates the endocytic uptake and degradation of advanced glycation endproducts of the Maillard reaction. Eur J Biochem, 230 : 408-415, 1995

11) Higashi $T$, Saishoji T, Ikeda $K$, Sano H, Jinnouchi $Y$, Takeya M, Kanzaki T, Morisaki N, Rauvala H, Takahashi K, Shichiri M, and Horiuchil S: The Noven Receptor for Advanced Glycation End Products Mediates The Chemotaxis of Smooth Muscle Cell. Diabettes in subumission.

12) Freeman M, Ekkel Y, Rohrer L, Penman M, Freemam, N.J, Chisolm G.M, and Krieger, M : Expression of type and type II bovine scavenger receptor in Chinese hamster ovary cells: lipid droplet accumulation and nonreciprocal cross competition by acetylated and oxidized low density lipoprotein. Proc Natl Acad Sci USA, 88: 4931-4935 1991

13) Yui S, Sasaki T, Araki N, Horiuchi S, and Yamazaki $\mathrm{M}$ : Irduction of macrophage growth by advanced glycation end products of the Maillard reaction. J Immunol, 152: 1943-1949, 1994

14) Saishoji T, Higashi T, Ikeda K, Sano H, Jinnouchi $Y$, Ogawa $\mathrm{M}$, and Horiuchi, S : Advanced grycation endproducts of the Maillard reaction stimulate plasminogen activitr via GM-CSF is RAW 264.7 cells. Biochem Biophys Res Commun, 230 : 408-415, 1995

15) Seikoh Horiuchi: AGE-modified proteins and their potential relevance to atherosclerosis. Trends in Cadiovascular Medicine, 6: 1996. (in press)

\title{
Summary
}

\section{Pathophysiological Role of AGE in Atherosclerosis}

\author{
Takayuki HIGASHI ${ }^{1,2)}$, Shuichi KumE ${ }^{3)}$, Kazuyoshi IKEDA $^{1)}$, Tetsushi SAISHOJI ${ }^{1)}$, \\ Hiroyuki SANO ${ }^{1)}$, Yoshiteru JinNOUCHI ${ }^{1}$, Ryoji NAGAI ${ }^{1}$, Kiyoshi TAKAHASHI ${ }^{3}$, \\ Motoaki SHICHIRI ${ }^{2)}$, and Seikoh HoRIUCHI ${ }^{1)}$
}

\author{
${ }^{1)}$ Department of Biochemistry, ${ }^{2}$ Department of Metabolic Medicine, and \\ ${ }^{3)}$ Second Department of Pathology, Kumamoto University School of Medicine, Kumamoto, Japan
}

Long-term incubation of proteins with glucose leads to advanced glycation end products (AGE) with fluorescence and a brown color. We recently immunologically demonstrated the intracellular AGE-accumulation in macrophage and smooth muscle cell (SMC)-derived foam cells in the human advanced atherosclerotic lesions by using antibody against AGE. Immunoelectron microscopic observation also revealed the localization of AGE in lysosomal lipid vacuoles, or electron-dense granules of the foam cells. To understand the mechanism of AGE-accumulation in these foam cells, we characterized the interaction of AGE-proteins with macrophage and SMC.

In the present study, we examined whether macrophage scavenger receptor (MSR) could mediate the endocytic uptake of AGE-proteins by using Chinese hamster ovary cells overexpressing bovine type II MSR (CHO-SRII). ${ }^{125}$ I-AGE-bovine serum albumin ( ${ }^{125} \mathrm{I}-$ 
AGE-BSA) as well as ${ }^{125}$ I-acetylated low density lipoprotein ( ${ }^{125}$ I-acetyl-LDL) underwent endocytic degradation by CHO-SRII cells, but not by control $\mathrm{CHO}$ cells. Endocytic degradation of ${ }^{125} \mathrm{I}$-acetyl-LDL and ${ }^{125} \mathrm{I}$-AGEBSA by CHO-SRII cells was significantly inhibited by unlabeled AGE-BSA, as well as by acetyl-LDL. Moreover, the endocytic uptake of ${ }^{125}$ I-AGE-BSA by peritoneal macrophages from MSR knock out mice was decreased $70-80 \%$ as compared with that of control. We recently demonstrated that the cell growth of starchinduced mouse peritoneal macrophages was induced by AGE-proteins. This AGE-induced macrophage growth was accompanied by a significant induction of granulocyte/monocyte colony stimulating factor (GMCSF) at the mRNA level, and was effectively inhibited by an anti-GM-CSF antibody, suggesting that AGEproteins may stimulate macrophages to secrete GM-CSF, which might stimulate cell growth in an autocrine or paracrine fashion.

In experiments by using rabbit SMC, ${ }^{125}$ I-AGE-BSA showed a dose-dependent saturable binding with an apparent dissociation constant (Kd) of $4.0 \mu \mathrm{g} / \mathrm{ml}$ at $4^{\circ} \mathrm{C}$. In experiments at $37^{\circ} \mathrm{C}$, AGE-BSA underwent receptormediated endocytosis and subsequent lysosomal degradation. The endocytic uptake of ${ }^{125}$ I-AGE-BSA was effectively inhibited by unlabeled AGE-proteins such as AGE-BSA and AGE-hemoglobin, but not by acetylLDL and oxidized LDL, well-known ligands for MSR. These results indicate that the endocytic uptake of AGE-proteins by SMC is mediated by an AGE receptor which is different from MSR. To determine the functional role of this AGE receptor, the effects of AGE-BSA on the cell migration of these SMC were examined. Incubation of SMC with $1-100 \mu \mathrm{g} / \mathrm{ml}$ of AGE-BSA resulted in the significant cell migration.

Based on our findings, we will discuss the pathophysiological role of AGE in atherosclerosis.

Key words : AGE, Macrophage, SMC, MSR, AGEreceptor 